\title{
MODEL PROTOTYPE SEBAGAI METODE PENGEMBANGAN PERANGKAT LUNAK PADA SISTEM INFORMASI PENGADUAN UMUM (STUDI KASUS : DINAS PERHUBUNGAN PROVINSI KALIMANTAN BARAT)
}

\author{
Eva Meilinda[1]; Raja Sabaruddin[2]; Dewi Fitriani[ ${ }^{[3]}$ \\ Program Studi Sistem Informasi [1][3]; Program Studi Sistem Informasi Akuntansi[2] \\ Universitas Bina Sarana Informatika Kampus Kota Pontianak \\ eva.emd@bsi.ac.id[1]; raja.rjd@bsi.ac.id[2]; dewifitriani656@gmail.com[3]
}

\begin{tabular}{|c|c|}
\hline INFO ARTIKEL & INTISARI \\
\hline $\begin{array}{l}\text { Diajukan : } \\
\text { 04 Agustus } 2021 \\
\text { Diterima : } \\
25 \text { Agustus } 2021 \\
\text { Diterbitkan: } \\
01 \text { Desember } 2021 \\
\text { Kata Kunci : } \\
\text { Pelayanan, Masyarakat, Pelayanan } \\
\text { Umum }\end{array}$ & $\begin{array}{l}\text { Dinas Perhubung Kalimantan Barat adalah sebuah otonomi daerah yang } \\
\text { terletak di jalan Adi sucipto No. 8a, Sungai Raya, Kabupaten Kubu Raya, } \\
\text { dipimpin oleh Drs. Manto, M.S.I sebagai direktur utama. Memiliki } 1 \\
\text { sekretaris, } 15 \text { kasi, } 2 \text { Ka. TU. UPTD dan } 153 \text { karyawan. Saat ini dinas } \\
\text { perhubungan memiliki } 4 \text { golongan karyawan dengan jumlah karyawan } \\
\text { sebanyak } 112 \text {. Berdasarkan dari hasil observasi, permasalahan yang terjadi } \\
\text { di Dinas Perhubungan yaitu, sulitnya dalam melakukan pengaduan } \\
\text { perbaikan jalan, perbaikan lampu lalu lintas dan taman kota, masyarakat } \\
\text { harus datang langsung ke Dinas Perhubungan dan membuang waktu lama } \\
\text { untuk menunggu tanggapan dari pihak kantor, hal ini tentunya dapat } \\
\text { membuat pihak masyarakat akan merasa sangat sulit dan terlalu lama } \\
\text { untuk menunggu perbaikan jalan. Dengan merancang Rancangan aplikasi } \\
\text { Pengaduan umum berbasis website pada Dinas Perhubung Kalimantan } \\
\text { Barat. Untuk pengggunaan metode pengembangan perangkat lunak penulis } \\
\text { memanfaatkan model prototype. Rancangan ini diharapkan dapat } \\
\text { memudahkan masyarakat dalam melakukan pengaduan dan pengajuan } \\
\text { perbaikan jalan tanpa harus datang langsung ke dinas perhubungan dan } \\
\text { rancangan sistem ini diharapkan meningkatkan kinerja dinas perhubungan } \\
\text { dalam melakukan pelayanan untuk masyarakat. }\end{array}$ \\
\hline
\end{tabular}

\section{PENDAHULUAN}

Dinas Perhubungan Provinsi Kalimantan Barat merupakan salah satu dinas yang juga menerima beberapa pengaduan umum dari masyarakat. Sistem pengaduan yang dimaksud ialah sistem yang dapat memberikan pelayanan beberapa aduan masyarakat yang berhubungan dengan perbaikan jalan, perbaikan rambu dan perawatan lalu lintas. Kinerja sistem dalam melaksanakan pelayanan aduan yang saat ini dilakukan pada Dinas Perhubungan Provinsi Kalimantan barat masih dinilai sangat kurang karena dikelola secara konvensional. Oleh karena itu pelayanan pada Dinas Perhubungan Provinsi Kalimantan barat dirasa belum sempurna, karena media yang digunakan masih dinilai kurang lambat untuk merespon aduan-aduan yang disampaikan. Perancangan Sistem Informasi pengaduan Umum ini di harapkan dapat membantu masyarakat dalam memberikan aduan atau perbaikan lampu lalu lintas di Kota Pontianak, serta dapat menjadikan pihak Dinas gesit dalam merespon setiap aduan dan membrikan kemudahan dalam mengelola setiap pengaduan yang didapat.

Pelayanan kerja pada perusahaan sangat penting, hal ini sebagai salah satu visi dan misi dalam melayani masyarakat terutama di bidang perawatan lampu lalu lintas, memelihara taman dan perawatan kota, sehingga dapat membantu karyawan untuk mencapai tujuan bersama, salah satunya adalah tercapainya target kerja.

Banyaknya keresahan yang disampaikan oleh masyarakat terhadap kondisi lampu lalu lintas yang mengalami kerusakan terkesan tidak diberi tanggapan karena belum tersedianya jembatan yang menjadi penghubung yang baik bagi masyarakat dan pemerintah dalam menanggapi permasalahan yang diadukan oleh masyarakat. Maka dari itu, penulis mencoba membuat jembatan tersebut agar segala keluhan dan keresahan yang masyarakat adukan dapat dikelola dengan baik oleh Dinas Perhubungan Provinsi Kalimantan Barat.

Dalam merancang sistem ini, terdapat beberapa teori yang dibutuhkan. "Suatu sistem pada dasarnya adalah kelompok unsur yang 
berhubungan erat satu dengan yang lainya, yang berfungsi bersama-sama untuk mencapai tujuan tertentu" (Rasefta \& Esabella, 2020). Dalam pengertian lain juga menyebutkan yaitu "suatu kombinasi terartur perorangan, hardware (perangkat keras), software (piranti lunak), jaringan komputer dan komunikasi data dan basis data dalam mengumpulkan, menyebarkan, dan merubah informasi dalam suatu bentuk organisasi". (Firmansyah et al., 2020).

Selain itu, suatu system yang memiliki karakteristik pasti memiliki komponens system atau juga di sebut component, batas system atau jufa di sebut boundary, lingkungan luar system atau juga di sebut environment, penghubung atau juga disebut interface, masukan atau input, pengolahan atau process, keluaran atau output dan sasaran atau objective serta tujuan atau goals.(Lan, 2019). Dan sistem juga memiliki klasifikasi, diambil dari sebuah teori yang menuliskan bahwa klasifikasi sistem merupakan suatu proses yang memiliki tujuan tertentu. Menurut ahli lain, juga mengatakan klasifikasi sistem adalah tahapan terhadap suatu model yang mengelompokkan suatu objek sesuai dengan porsinya seperti sistem memiliki tingkah laku yang berbeda dengan sistem yang lain (Mahmudah et al., 2016).

Selain itu juga dibutuhkan teori mengenai sistem informasi. System informasi merupakan tempat atau wadah sebagai tempat penyimpanan informasi sehingga mendukung dalam mengambil keputusan atau kepastian dalam melaksanakan operational dari sekumpulan orang, teknologi yang digunakan maupun organisasi yang membubtuhkan. (Maryani, 2020). Pendapat lain menyimpulkan system informasi merupakan kebutuhan user dalam mengembangkan suatu kegiatan ataupun organisasi. (Anang, 2019).

\section{BAHAN DAN METODE}

Dalam penelitian ini, penulis mengimplementasikan model prototype sebagai metode pengembangan perangkat lunak pada rancangan sistem informasinya. Metode prototype merupakan sebuah metode yang mengembangkan aplikasi dengan cara memberikan contoh penawaran sebuah rancangan kepada orang yang akan menjadi pemakai aplikasi dan memberikan evaluasi prototype sebelum dilakukan penulisan syntak.

Dalam penggunaan metode ini, calon pengguna atau pemakai juga ikut berperan dalam proses pembuatan aplikasi dan penggunaan prinsip-prinsip keahlian teknik untuk mendapatkan perangkat lunak yang ekonomis yang handal dan bekerja secara efisien (Indahningrum, 2020).

Pada model prototype, terdapat 4 tahapan yang biasanya harus dilalui atau dilakukan oleh perancang, yaitu :

1. Mendengarkan Kebutuhan

Mengetahui permasalahan-permasalahan yang sedang terjadi, adapun hasil dari wawancara ini adalah, penulis bisa mendapatkan bagaimana sistem berjalan yang sedang diterapkan pada kantor, serta

2. Membangun rancangan atau Mock-Up Setelah melakukan analisa kebutuhan tentang pengajuan izin usaha kemudian penulis melakukan pembuatan jadwal rencana yang dikerjakan, pembuatan rancangan ini dengan menggunakan beberapa bahasa PHP, HTML, CSS dan framework.

Permodelan yang digunakan dalam rancangan ini yaitu activity diagram, use case diagram, class diagram, dan untuk rancangan databse menggunakan entity relation diagram, logival record structure.

3. Pengujian mock-up

Tahap ini merupakan tahap atau langkah terakhir dari model prototype ini bertujuan untuk mendapatkan tanggapan dan mendapatkan kepuasan dari pihak kantor dan pihak pengaju izin usaha atas sistem yang sudah dibuat atau dirancang. Dan proses tersebut dilakukan harus sesuai urutan.

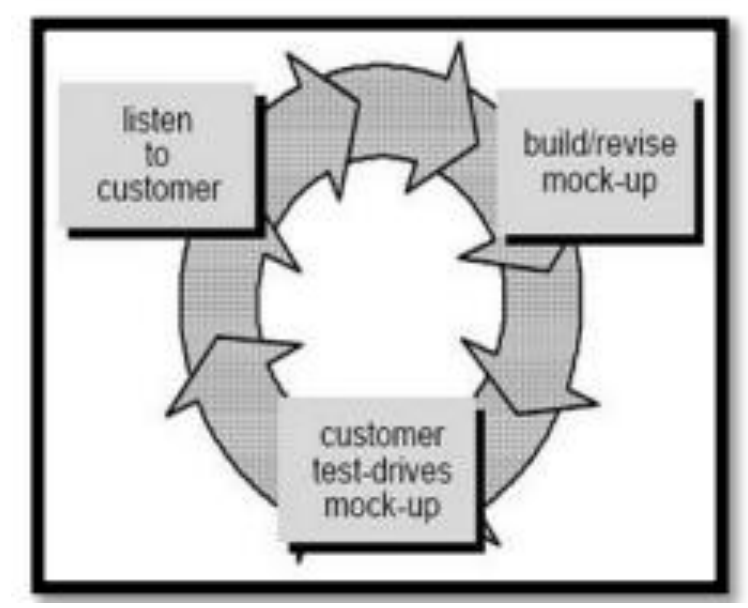

Sumber : (Fajarianto, 2016)

Gambar 1. Model Prototype

Dalam melakukan rancang bangun sistem informasi ini, untuk mengetahui apa yang menjadi kebutuhan yang pengguna harapkan, yaitu dengan merancang use case digram terlebih dahulu. Berikut gambar use case yang di buat. 


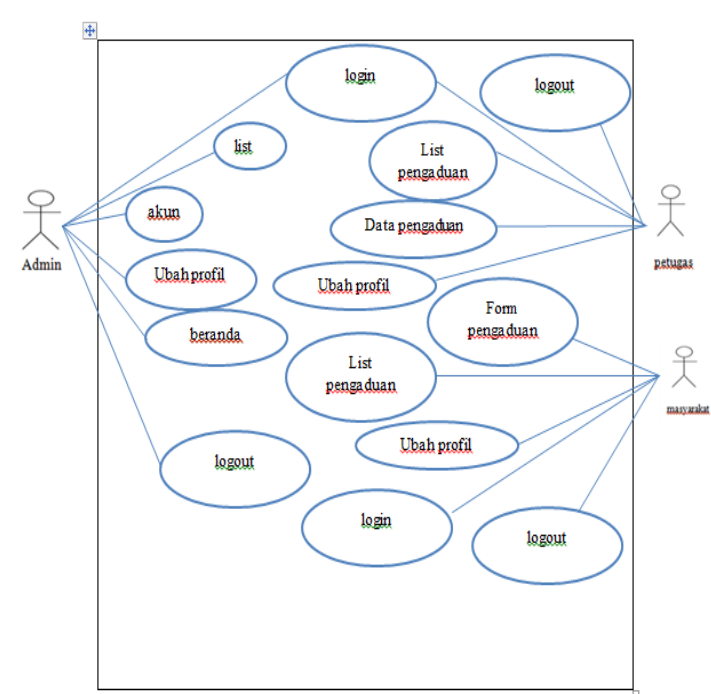

Sumber : Hasil Penelitian (2021)

Gambar 2. Use Case Diagram

Selain itu, penulis juga menggunakan rancangan activity diagram guna melihat beberapa transaksi yang harus ada pada sistem yang dirancang.

Berikut bentuk activity diagram hasil rancangan :

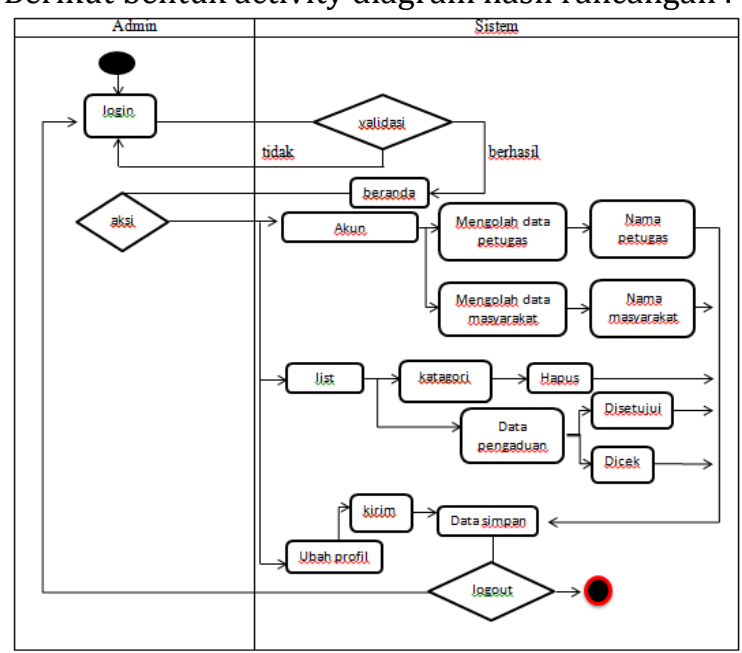

Sumber : Hasil Penelitian (2021)

Gambar 3. Activity Diagram Admin

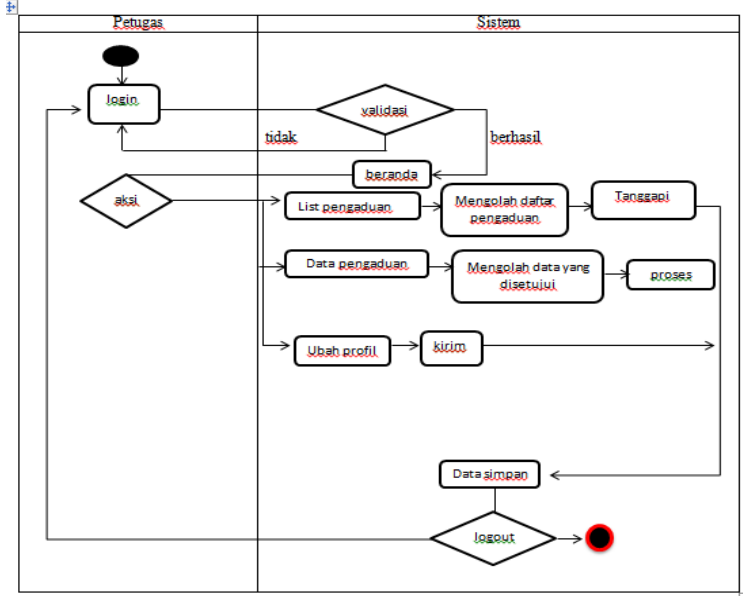

Sumber : Hasil Penelitian (2021)

Gambar 4. Activity Diagram Petugas

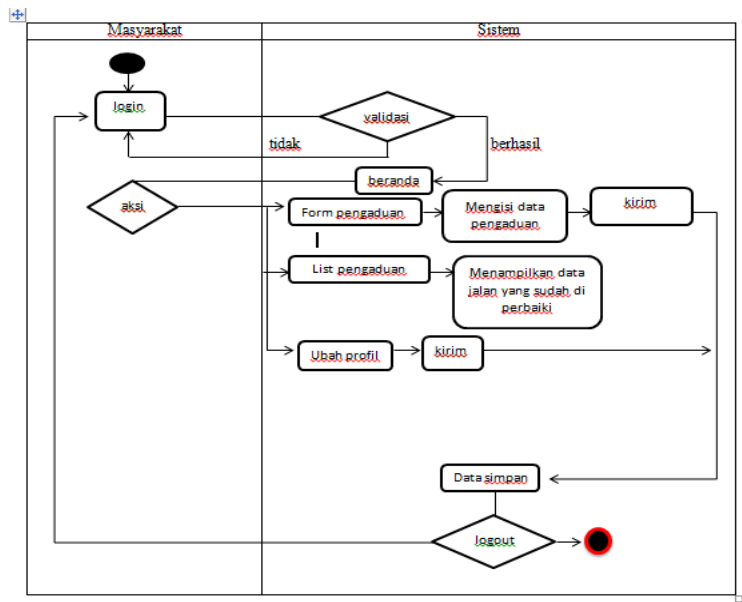

Sumber : Hasil Penelitian (2021)

Gambar 5. Activity Diagram Masyarakat

Sebagai pemetaan basis data, maka digambarkan dengan menggunakan ERD, yaitu :

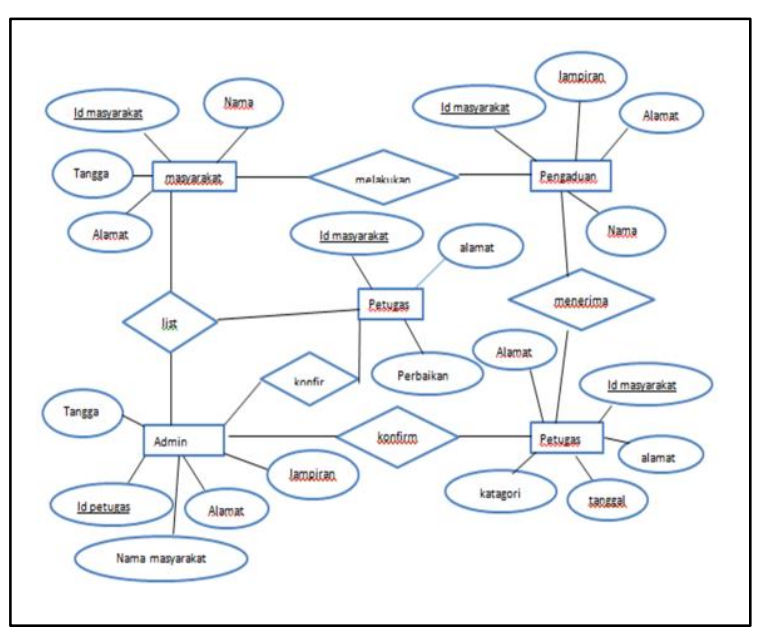

Sumber : Hasil Penelitian (2021)

Gambar 6. Rancangan ERD 
Dari rancangan ERD diatas, dapat dapat diberikan pula untuk rancangan LRS.

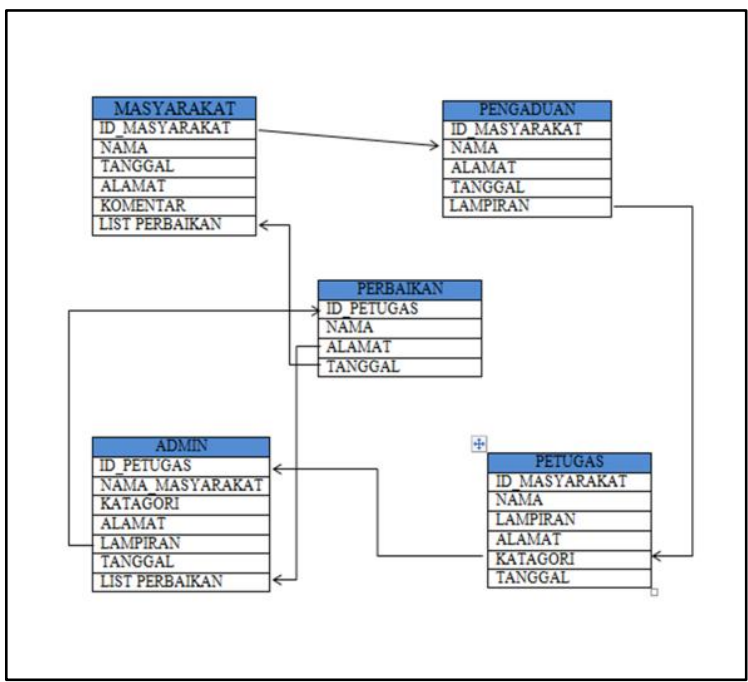

Sumber : Hasil Penelitian (2021)

Gambar 7. Rancangan LRS

Berikutnya terdapat class diagram yang berfungsi untuk memodelkan data rancangan dalam mengembangakan system ini.

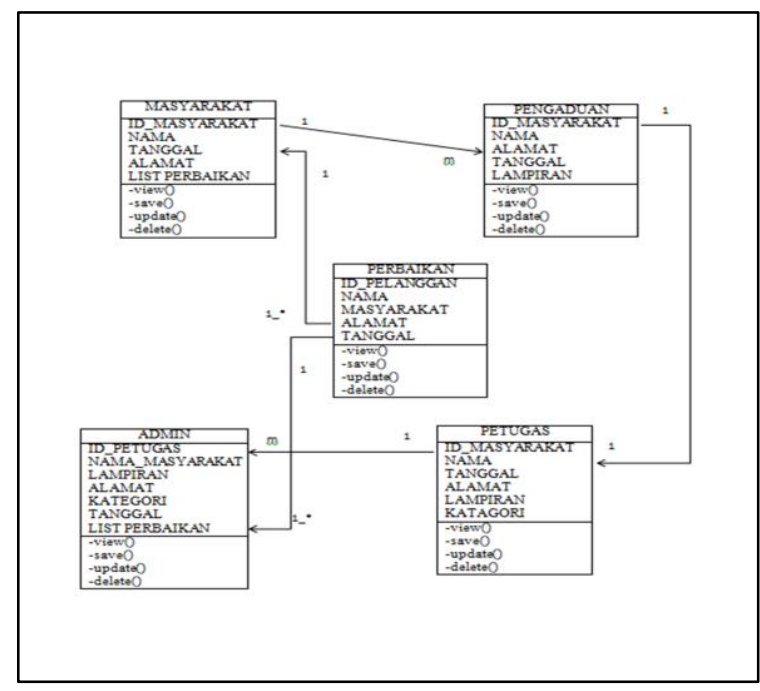

Sumber : Hasil Penelitian (2021)

Gambar 8. Rancangan Class Diagram

Untuk proses pembuatan alur dari program pada sistem atau aplikasi, maka penulis membuatkan gambar rancangan sequence diagram, yaitu :

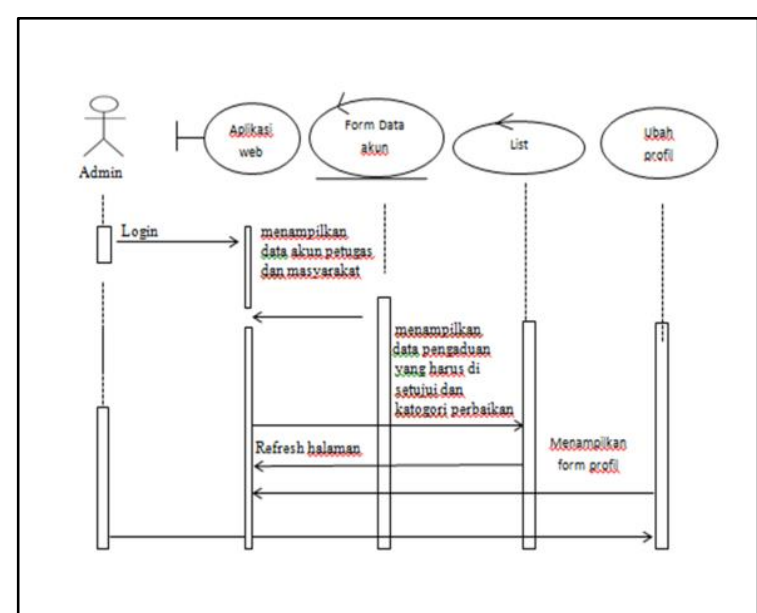

Sumber : Hasil Penelitian (2021)

Gambar 9. Rancangan Sequence Diagram Admin

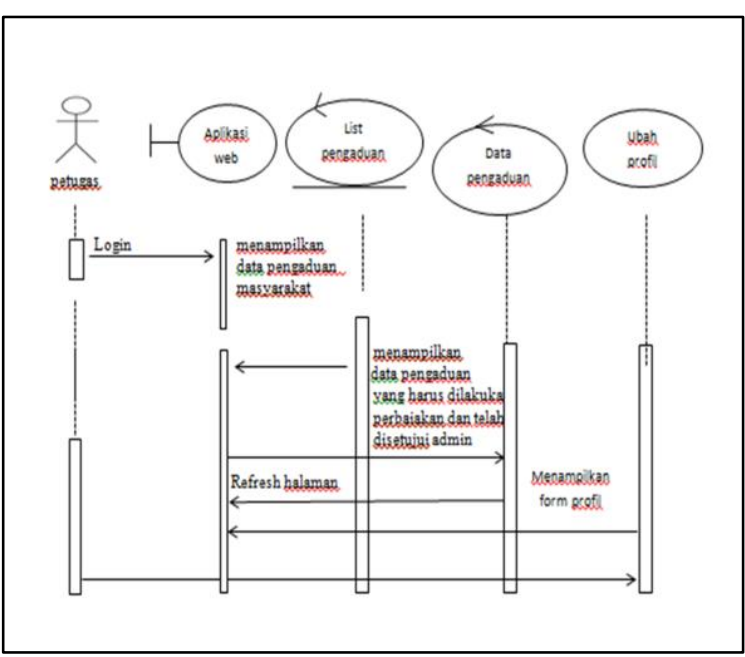

Sumber : Hasil Penelitian (2021)

Gambar 10. Rancangan Sequence Diagram Petugas

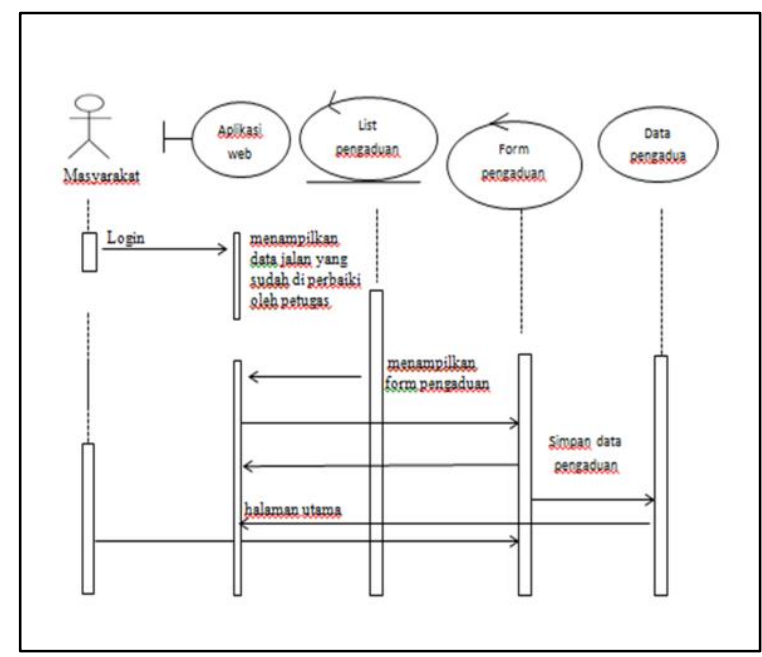

Sumber : Hasil Penelitian (2021)

Gambar 11. Rancangan Sequence Diagram Masyarakat 


\section{HASIL DAN PEMBAHASAN}

Setelah tahapan rancangan selesai maka penulis merancang desain antaramuka yang akan di buat, berikut desain antarmuka yang penulis desain.

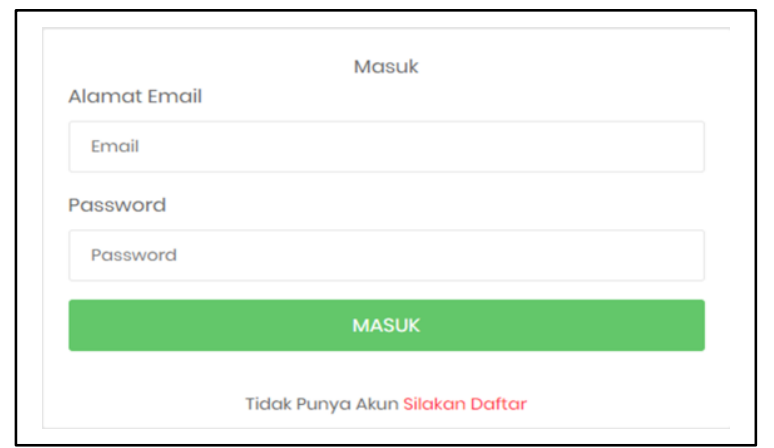

Sumber : Hasil Penelitian (2021)

Gambar 12. Interface Halaman Login

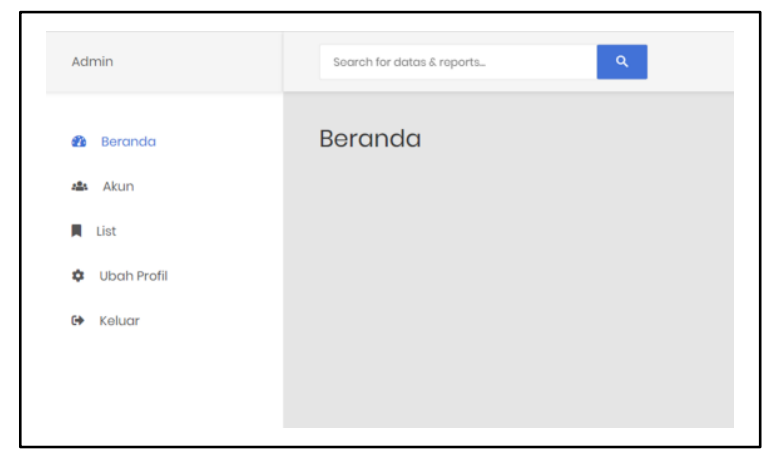

Sumber : Hasil Penelitian (2021)

Gambar 13. Interface Halaman Utama Admin

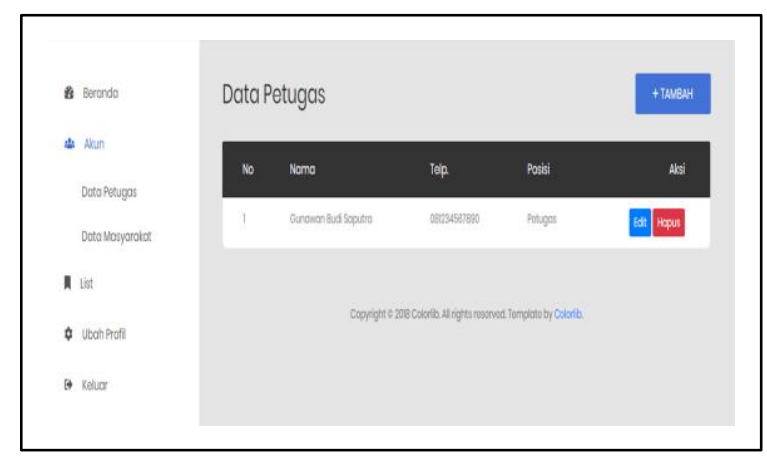

Sumber : Hasil Penelitian (2021)

Gambar 14. Interface Menu Akun Data Petugas

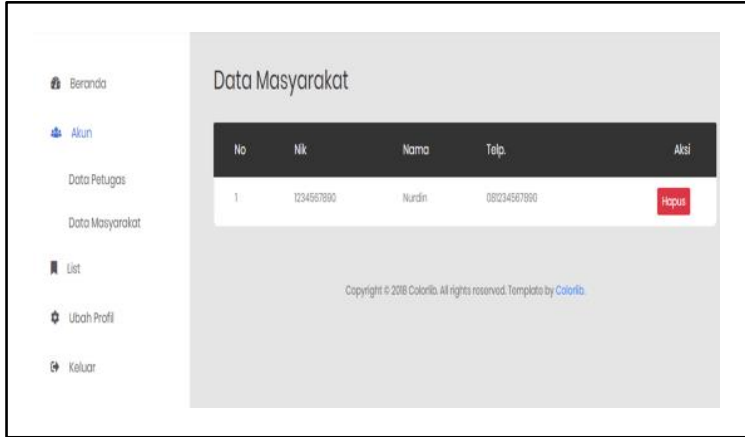

Sumber : Hasil Penelitian (2021)

Gambar 15. Interface Menu Akun Data Masyarakat

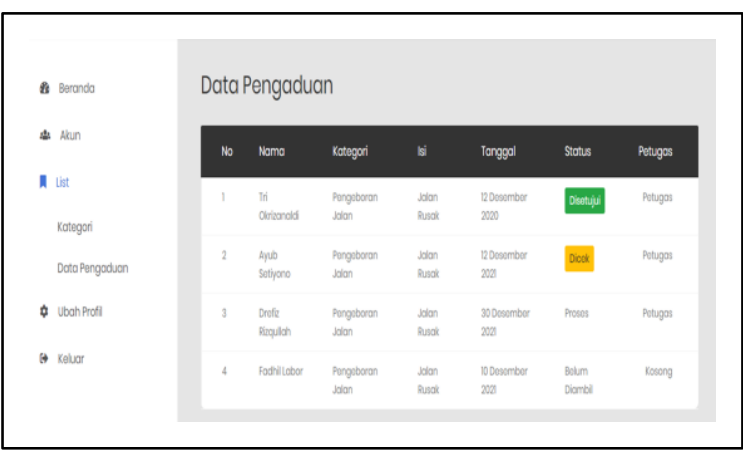

Sumber : Hasil Penelitian (2021)

Gambar 16. Interface Menu Data Pengaduan

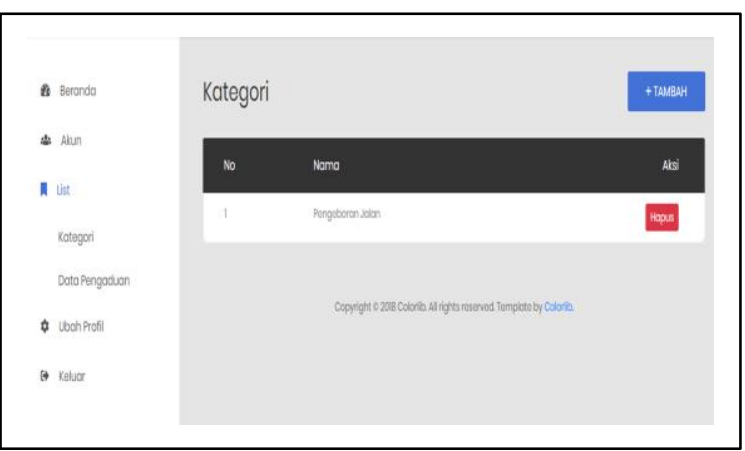

Sumber : Hasil Penelitian (2021)

Gambar 17. Interface Menu Kategori Perbaikan

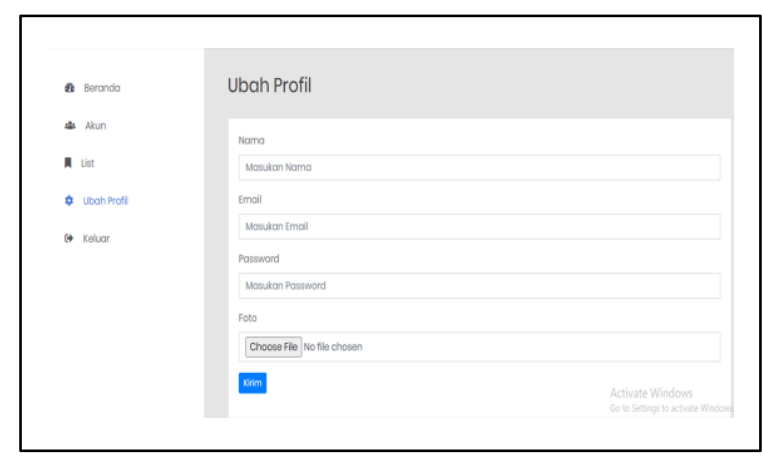

Sumber : Hasil Penelitian (2021)

Gambar 18. Interface Menu Ubah Profil 


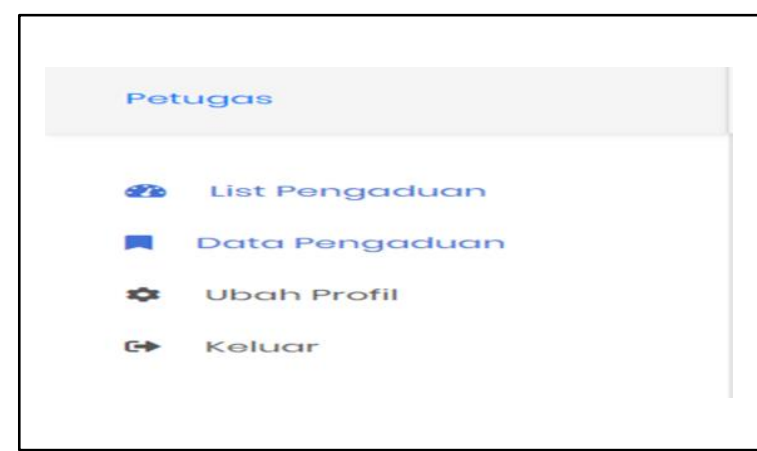

Sumber : Hasil Penelitian (2021)

Gambar 19. Interface Menu Utama Petugas

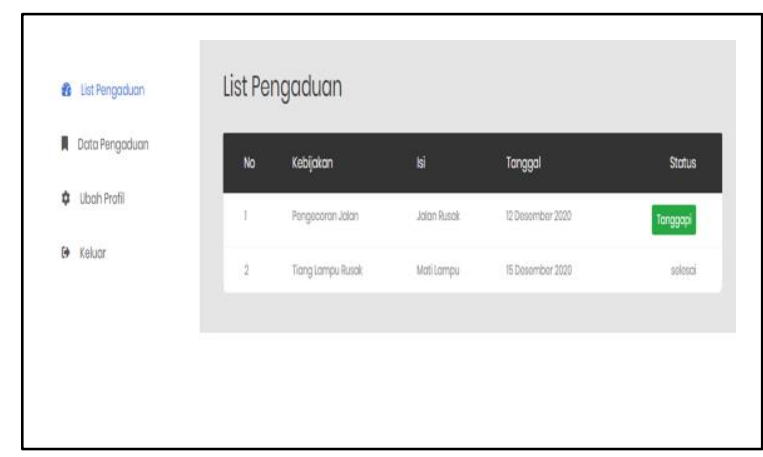

Sumber : Hasil Penelitian (2021)

Gambar 20. Interface Menu List Aduan

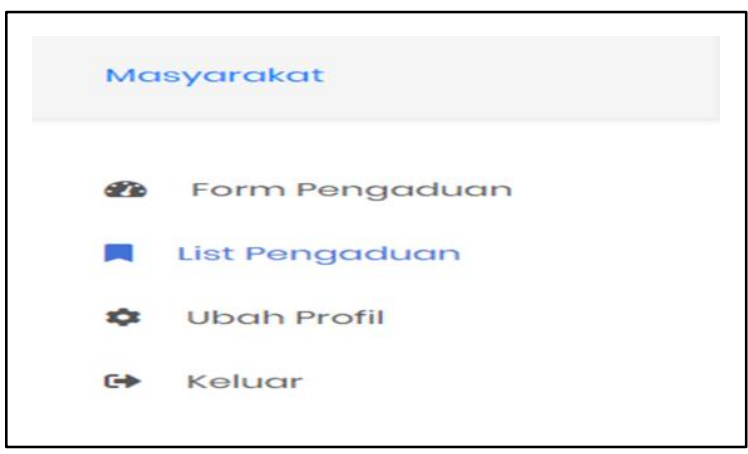

Sumber : Hasil Penelitian (2021)

Gambar 21. Interface Menu Utama Masyarakat

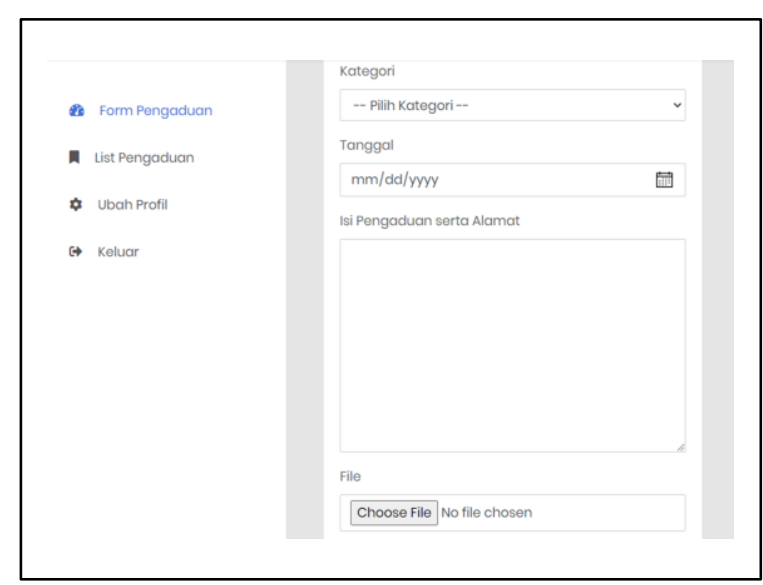

Sumber : Hasil Penelitian (2021)

Gambar 22. Interface Menu Input Pengaduan

\section{KESIMPULAN}

Dari hasil penelitian yang dipaparkan oleh penulis, terdapat beberapa hal yang diharapkan, diantaranya dengan adanya system informasi Rancangan aplikasi Pengaduan umum berbasis website pada Dinas Perhubung Provinsi Kalimantan Barat yang bersipat online, dapat memiliki gambaran tentang sistem pengaduan, perbaikan jalan, lampu lalu lintas dan taman kota sehingga kedepannya jika sistem serupa sudah ada dan rancangan ini dapat dijadikan sebuah aplikasi yang sudah benar-benar siap dipakai, maka diharapkan dapat membantu dalam proses pemecahan masalah yang sedang terjadi Dinas Perhubungan Provinai Kalimnatan Barat serta sebagai gambaran untuk memudahkan masyarakat untuk melakukan pengaduan, perbaikan jalan dan perbaikan taman kota, masyarakat tidak perlu lagi harus datang ke kantor, cukup lewat website Dinas Perhubungan.

Penulis memilih mengimplementasikan model prototype karena dapat menampung segala kebutuhan yang dibutuhkan user sebagai pengguna dalam merancang sistem yang nantinya dapat dimanfaatkan dengan baik.

\section{REFERENSI}

Anang, H. (2019). SISTEM INFORMASI PENJUALAN BUKU ( Studi Kasus Toko Buku Mulya Kecamatan Besuki, Situbondo ). 1, 105-113.

Firmansyah, Y., Maulana, R., \& Fatin, N. (2020). Sistem Informasi Pengaduan Warga Berbasis Website ( Studi Kasus : Kelurahan Siantan Tengah , Pontianak Utara ). Jurnal Cendikia, XIX(April), 397-404.

Indahningrum, R. putri. (2020). No 主観的健康感

$$
\begin{aligned}
& \text { を中心よした在宅高齢者における健康関連 } \\
& \text { 指標に関する共分散構造分析Title. 2507(1), } \\
& \text { 1-9. }
\end{aligned}
$$

Kotler. (1998). Sistem Informasi Pemesanan Dan Pembayaran Pada Percetakan Mahardika. On Computer Science - Speed - FTI UNSA.

Lan, K. B. (2019). 729-Article Text-2577-1-1020190628. 4(1).

Mahmudah, K., Mentari, M., Studi, P., Informatika, T., Informasi, J. T., Malang, P. N., \& Roges, R. (2016). PENGEMBANGAN SISTEM INFORMASI DISSOLVED GAS ANALYSIS ( DGA ). $12,54-59$.

Maryani, T. (2020). Pengaruh Partisipasi Pemakai Sistem Informasi, Kemampuan Pemakai Sistem Informasi, Ukuran Organisasi, Program Pelatihan Dan Pendidikan Terhadap Kinerja Sistem Informasi Akuntansi. Prisma (Platform Riset Mahasiswa 
Akuntansi), 1(1), 36-46.

Rasefta, R. S., \& Esabella, S. (2020). Sistem

Informasi Akademik Smk Negeri 3 Sumbawa

Besar Berbasis Web. Jurnal JINTEKS, 2(1),

50-58. 